\title{
Autologous stem cell transplantation in Kuwait cancer control centre: Review of infections in the first thirty days post-transplant
}

\author{
S. H. Alshemmari ${ }^{1}$, Samar Refaat ${ }^{2}$ \\ 1. Department of Medicine, Kuwait University, Kuwait. 2. Department of Medical Oncology, HMJ Cancer Center, Kuwait.
}

Correspondence: Salem Alshemmari. Address: Department of Medicine, Faculty of Medicine, Kuwait University, State of Kuwait, P.O.BOX 24923-13110 Safat. Telephone: 965-2531-9596, Fax: 965-2533-8907. E-mail: salem61@gmail.com

Received: April 15, 2012

DOI : $10.5430 /$ jhm.v2n2p39
Accepted: May 20, 2012

URL: http://dx.doi.org/10.5430/jhm.v2n2p39

\begin{abstract}
Autologous peripheral blood stem cells (PBSC) following high-dose chemotherapy is established in Kuwait Cancer Control Center since 2000. We studied the incidence of microbial infections during the first 30 days following autologous PBSC transplantation in 120 consecutive patients with non-Hodgkin's lymphomas, Hodgkin's lymphoma, multiple myeloma, and acute myeloid leukemia. The incidence and consequences of these infections are reported. All the patients received antibiotic prophylaxis and hematopoietic growth factors during neutropenia. The mean duration of severe neutropenia was 7 days (Range 5-9) in all the patients, and the median time to myeloid engraftment was 11 days. The incidence of culture-proven infections in non-Hodgkin's lymphoma, Hodgkin's lymphoma, and multiple myeloma patients was similar. Infections could be documented clinically only in 67 patients $(72.8 \%)$ where they had culture-negative infections. In 25 patients clinical infection was supported by positive cultures. The isolated organisms included Gram-negative organisms in 56\%, Gram positive in $24 \%$, and both Gram negative and Gram positive in $16 \%$ of the patients. In $4 \%$ of the patients fungi were isolated. The most common sites of infections were central line (catheter) infection (68\%). Among central line infections, isolates were Gram positive in 35.3\%, Gram negative in 41.2\%, both Gram negative and Gram positive in one patient and fungi in one patient. Although the overall incidence of infections among autologous SCT recipients is modest, because patients tended to have rapid recovery of their immune system, infections remain a significant cause of morbidity stressing the importance of prevention and management of infectious diseases.
\end{abstract}

\section{Key words}

Autologous stem cell transplant, Infections, Kuwait

\section{Introduction}

Autologous Stem Cell Transplantation in Kuwait has been performed since 2000. The program serves all the population of Kuwait. In 2009, the estimated population of Kuwait was 3.5 million, including 1.1 million (31.4\%) Kuwaitis and 2.4 million (68.6\%) non-Kuwaitis ${ }^{[1]}$. Expatriates and their family's resident in Kuwait have an equal chance, like Kuwaitis, to receive Autologous Stem Cell Transplantation in the Kuwait Cancer Control Center (KCCC). 
High-dose chemotherapy with autologous peripheral blood stem cell (PBSC) or bone marrow (BM) transplantation has become accepted consolidation or salvage therapy for various hematologic malignancies in patients aged $\leq 65$ years ${ }^{[1,2]}$.This approach is associated with improved response rates, overall survival, and event- free survival compared to conventional chemotherapy. A number of non-randomized ${ }^{[3-6]}$, randomized $^{[7-9]}$ and population-based studies ${ }^{[10]}$ as well as two recent meta-analyses have supported these observations ${ }^{[11,12]}$. Infections remain a significant cause of morbidity in this brief post-transplant neutropenia, despite rapid hematopoietic reconstitution with the use of mobilized autologous peripheral blood stem cell grafts, the use of hematopoietic growth factors after transplant, antibacterial, antiviral and antifungal prophylaxis as well as the transfusion support which reduced morbidity and mortality by shortening post-transplant neutropenia and its attendant complications ${ }^{[13-15]}$.

We have analyzed the microbial etiology of infections in 120 consecutive patients with Non-Hodgkin's and Hodgkin's lymphoma and multiple myelomas who received high dose chemotherapy and autologous stem cell transplant. We reviewed all episodes of infections occurring in first 30 days following autologous PBSC transplantation. The frequency, pattern of microbial infections, and consequences of these infections reflected on the transplant related mortality are reported.

\section{Patients and methods}

Between January 2000 and November 2010, 120 patients with non-Hodgkin's and Hodgkin's lymphoma, multiple myeloma, few cases of acute myeloid leukemia and one case of testicular seminoma received high dose chemotherapy and underwent autologous peripheral blood stem cell transplantation. Patients have given consent to use the clinical information contained in their treatment records for clinical analysis and publications for scientific communities. Nationalities of the patients were reported because ethnic, sociocultural, and economic factors have a significant impact on different aspects of cancer care including prevention, screening and early detection, treatment, enrollment in clinical trials, survivorship, palliative care, and end-of-life care ${ }^{[16,17]}$. In addition to these factors, expatriates are exposed to expatriationrelated stressors ${ }^{[18,19]}$. Patient characteristics are shown in Table 1 . There were 12 Kuwaiti male patients (54.5\%) with mean age $36.72 \pm 10.98$ years (Range, 16-54) and 10 (45.5\%) females, with mean age $43.22 \pm 14.95$ years (Range, 20-60). Within the Non-Kuwaiti group there were 69 (70.4\%) males, with mean age $38.24 \pm 11.91$ years (Age range 15-58) and 29 (29.6\%) females, with mean age $32.61 \pm 15.65$ years (Range 12-61). Among the Non-Kuwaiti patients there were 65 (66.3\%) Non-Kuwaiti Arab and other nationalities were 33 (33.7\%). Among the Non-Kuwaiti Arab the most common nationality was Egyptians 33 (33.7\%) patients followed by 8 Syrians patients (8.2\%). Among the Non-Kuwaiti other nationalities the most common nationality was Indians 21 patients $(21.4 \%)$ and followed by 7 Bengalis patients $(7.1 \%)$.

Table 1. Characteristics of patients undergoing autologous stem cell transplantation

\begin{tabular}{ll}
\hline No. & $\mathbf{1 2 0}$ \\
\hline Median age (Range) years & $42(12-61)$ \\
Sex & $81(67.5 \%)$ \\
Male & $39(32.5 \%)$ \\
Female & \\
Nationality & $22(18.3 \%)$ \\
Kuwaiti & $98(81.7 \%)$ \\
Non-Kuwaiti & \\
Diagnosis & \\
Group 1 & $45(37.5 \%)$ \\
Non-Hodgkin's lymphoma & $26(57.7 \%)$ \\
Low-grade non-Hodgkin's lymphoma & $19(42.3 \%)$ \\
Diffuse large B-cell lymphoma & \\
Group 2 & $36(30 \%)$ \\
Hodgkin's disease & $33(27.5 \%)$ \\
Group 3 &
\end{tabular}

Shown are number (\%) of patients with specific characteristics. 
The age at autologous stem cell transplantation in the three groups is shown in table 2

Table 2. Age at autologous stem cell transplantation

\begin{tabular}{llllllll}
\hline Diagnosis & & Nationality & \multicolumn{2}{l}{ Age at transplant } & & & Min \\
& & & Mean & Median & Sd & Max \\
\hline Non-Hodgkin's & Low-grade & Kuwaiti & 51.86 & 53 & 8.71 & 34 & 60 \\
lymphoma & & Non-Kuwaiti & 45.06 & 48.5 & 11.12 & 24 & 61 \\
& Diffuse large & Kuwaiti & 38 & 36 & 5.29 & 34 & 44 \\
& B-cell & Non-Kuwait & 38.08 & 37 & 13.53 & 14 & 58 \\
Hodgkin's lymphoma & & Kuwaiti & 33.43 & 29 & 13.93 & 16 & 54 \\
& & Non-Kuwait & 29.57 & 28 & 10.98 & 12 & 52 \\
Multiple Myeloma & & Kuwaiti & 47.33 & 48 & 3.06 & 44 & 50 \\
& & Non-Kuwait & 47.4 & 48 & 6.98 & 34 & 57 \\
\hline
\end{tabular}

Patients' status at transplant is shown in table 3

Table 3. Status at autologous stem cell transplantation

\begin{tabular}{|c|c|c|c|c|c|}
\hline Diagnosis & \multicolumn{2}{|c|}{$\begin{array}{l}\text { Pre-transplant chemotherapy } \\
\& \text { No. of patients }\end{array}$} & $\begin{array}{l}\text { No. of patients } \\
\text { (\%) }\end{array}$ & $\begin{array}{l}\text { Status at transplant } \\
\text { No of patients }(\%) \\
\text { complete response }\end{array}$ & $\begin{array}{l}\text { No of patients }(\%) \\
\text { partial response }\end{array}$ \\
\hline Non-Hodgkin's $\quad$ Low-grade & $\mathrm{DHAP} \pm \mathrm{R}$ & 14 & & \multirow{5}{*}{$24(92.3)$} & \multirow{5}{*}{$2(7.7)$} \\
\hline \multirow[t]{4}{*}{ lymphoma } & DHAP + MINE + ESHAP & 1 & \multirow{4}{*}{$26(21.7)$} & & \\
\hline & ICE & 3 & & & \\
\hline & MINE & 3 & & & \\
\hline & $\mathrm{CHOP} \pm \mathrm{R}$ & 5 & & & \\
\hline Diffuse & $\mathrm{ESHAP} \pm \mathrm{R}$ & 11 & \multirow{3}{*}{$19(15.8)$} & \multirow{3}{*}{$16(84.2)$} & \multirow{3}{*}{$3(15.8)$} \\
\hline large B-cell & ESHAP + ICE & 3 & & & \\
\hline & HyperCVAD & 5 & & & \\
\hline \multirow[t]{6}{*}{ Hodgkin's lymphoma } & COPP & 1 & \multirow{6}{*}{$36(30.1)$} & \multirow{6}{*}{$31(86.1)$} & \multirow{6}{*}{$5(13.9)$} \\
\hline & MINE & 1 & & & \\
\hline & ESHAP + Radiotherapy & 1 & & & \\
\hline & $\begin{array}{l}\text { Gemzar }+ \text { Caleyx }+ \\
\text { Dexamethasone }\end{array}$ & 2 & & & \\
\hline & DHAP & 8 & & & \\
\hline & ICE & 23 & & & \\
\hline \multirow[t]{3}{*}{ Multiple myeloma } & VAD & 9 & \multirow{3}{*}{$33(27.2)$} & \multirow{3}{*}{\multicolumn{2}{|c|}{$\begin{array}{l}\text { autologous stem cell transplantation as } \\
\text { primary consolidation }\end{array}$}} \\
\hline & CTDa & 22 & & & \\
\hline & VTD & 2 & & & \\
\hline
\end{tabular}

Acute myeloid leukemia patients (4.2\%) five in CR2 \& CR3 and one Cancer testis patient (0.8\%) in CR3. These patients were not included in the analysis because of their small number.

The salvage chemotherapy used in 45 (36.7\%) Non-Hodgkin's lymphoma patients was DHAP $\pm \mathrm{R}$ [Cisplatin $100 \mathrm{mg} / \mathrm{m}^{2}$ day 1 , cytarabine $4(2 \mathrm{~g} / 12 \mathrm{~h}) \mathrm{g} / \mathrm{m}^{2}$ day 2, dexamethasone $40 \mathrm{mg} /$ day days $1-4$, with or without Rituximab $\left.375 \mathrm{mg} / \mathrm{m}^{2}\right]$ in 14 cases, DHAP was followed by MINE [Mesna and ifosfamide $1330 \mathrm{mg} / \mathrm{m}^{2}$ and etoposide $65 \mathrm{mg} / \mathrm{m}^{2}$ i.v. days $1-3$, and mitoxantrone $8 \mathrm{mg} / \mathrm{m}^{2}$ i.v. day 1 ) then ESHAP (Etoposide $40 \mathrm{mg} / \mathrm{m}^{2} /$ day IV Day 1, 2, 3 and 4, Solumedrol $500 \mathrm{mg} / \mathrm{m}^{2} /$ day IV Day 1, 2, 3, 4 and 5, Cytarabine 2Gm/ $\mathrm{m}^{2} /$ day IV Day 5 -To start immediately after Cisplatin completed, Cisplatin $25 \mathrm{mg} / \mathrm{m}^{2} /$ day IV Day 1,2, 3 and 4; Given as a continuous infusion over 24 hours] in 1 case, ESHAP $\pm \mathrm{R}$ in 11 cases, in one of them ESHAP was followed by radiotherapy, ESHAP was followed by ICE $\left\{\right.$ Ifosfamide $5000 \mathrm{mg} / \mathrm{m}^{2}$ intravenously (i.v.) fractionated into three equally divided doses over 3 days, carboplatin [mg dose $=5 \mathrm{x}$ area under the curve (AUC)] i.v. on day 1 and etoposide $100 \mathrm{mg} / \mathrm{m}^{2}$ i.v. daily for 3 days $\}$ in 3 cases, ICE was used in 3 cases, MINE (Mesna and ifosfamide 
$1330 \mathrm{mg} / \mathrm{m}^{2}$ and etoposide $65 \mathrm{mg} / \mathrm{m}^{2}$ i.v. days $1-3$, and mitoxantrone $8 \mathrm{mg} / \mathrm{m}^{2}$ i.v. day 1 ) was used in 3 cases, Hyper CVAD \{Hyper fractionated cyclophosphamide $300 \mathrm{mg} / \mathrm{m}^{2}$ b.i.d. i.v. ( $3 \mathrm{~h}$ infusion) day 1-3 with mesna uroprotection, vincristine $1.4 \mathrm{mg} / \mathrm{m}^{2}$ (Max 2mg) i.v. day 4+11 (12 h after cyclophosphamide), doxorubicin $16.7 \mathrm{mg} / \mathrm{m}^{2}$ day 4-6, and dexamethasone $40 \mathrm{mg}$ i.v. or p.o. day $1-4,11-14$, with growth factor support. Rituximab $375 \mathrm{mg} / \mathrm{m}^{2}$ i.v. day 0 , alternated with courses of high-dose methotrexate $200 \mathrm{mg} / \mathrm{m}^{2}$ i.v. ( $2 \mathrm{~h}$ infusion) day 1 followed by $800 \mathrm{mg} / \mathrm{m}^{2}$ i.v. Continuous infusion with folinic acid rescue, and cytarabine $3000 \mathrm{mg} / \mathrm{m}^{2}$ b.i.d. i.v. ( $2 \mathrm{~h}$ infusion) day $\left.2+3\right\}$ in 5 cases, and $\mathrm{CHOP} \pm \mathrm{R}$ [Cyclophosphamide (Cytoxan) $750 \mathrm{mg} / \mathrm{m}^{2}$ day 1 , doxorubicin (Adriamycin) $50 \mathrm{mg} / \mathrm{m}^{2}$ day 1 , vincristine (Oncovin) $1.4 \mathrm{mg} / \mathrm{m}^{2}$ (Max $2 \mathrm{mg}$ ) i.v. day 1 and prednisone $100 \mathrm{mg} /$ day p.o. days $1-5 \pm$ rituximab $375 \mathrm{mg} / \mathrm{m}^{2}$ i.v. day 1 ] in 5 cases. The salvage chemotherapy used in $36(30 \%)$ Hodgkin's lymphoma cases was COPP [Cyclophosphamide $500 \mathrm{mg} / \mathrm{m}^{2}$ i.v. day $1+8$, Vincristine $1.4 \mathrm{mg} / \mathrm{m}^{2}$ (Max 2mg) i.v. day 1+8, Prednisone $40 \mathrm{mg} / \mathrm{m}^{2}$ p.o. (3 doses) day 1-14, Procarbazine $100 \mathrm{mg} / \mathrm{m}^{2}$ (Max $150 \mathrm{mg}$ ) p.o. (2-3 doses) day 1-14] in 1 case, MINE in 1 case, ESHAP followed by radiotherapy 36 Gy in 1 case, Gemzar $1000 \mathrm{mg} / \mathrm{m}^{2}$, Navelbine $20 \mathrm{mg} / \mathrm{m}^{2}$, \& Caelyx $15 \mathrm{mg} / \mathrm{m}^{2}$ Gemzar, Navelbine, \& Caelyx were given day 1 and day 8 every 21 days in 2 cases, DHAP in 8 cases, and ICE in 23 cases. The pre-transplant chemotherapy used in 33 Multiple Myeloma cases was VAD [Vincristine $0.4 \mathrm{mg} / \mathrm{m}^{2}$ i.v. (Continuous infusion) day 1-4, Doxorubicin $9 \mathrm{mg} / \mathrm{m}^{2}$ i.v. (Continuous infusion) day 1-4, Dexamethasone 40mg/day i.v. day 1-4, days 9-12, and days 17-20] in 9 patients. CTDa [cyclophosphamide $500 \mathrm{mg}$ /day p.o. day $1,8,15,22$, thalidomide $50 \mathrm{mg} /$ day p.o. for 4 weeks increasing by $50 \mathrm{mg} /$ day every 4 weeks to 200mg/day, dexamethasone 20mg/day p.o. day1-4 and days 15-18 (Four-week cycle)] in 22 patients, and VTD (Bortezomib $1.3 \mathrm{mg} / \mathrm{m}^{2}$ IV on days $1,4,8$, and 11 plus thalidomide $200 \mathrm{mg}$ /day PO plus dexamethasone $40 \mathrm{mg} /$ day PO on days 1-4 and days 8-11) in 2 patients. The pre-transplant chemotherapy used in 5 AML cases FLAG [Fludarabine, Ara-C, G-CSF - (Growth factor)] in 2 cases and FLAG-IDA [G-CSF 5 micro $\mathrm{g} / \mathrm{kg}$ from day +6 until neutrophil recovery (Growth factor) given by injection under the skin in the tummy or leg from day 1 until counts recover, Fludarabine $30 \mathrm{mg} / \mathrm{m}^{2}$ given via an infusion (drip) over 30 minutes, once a day for 5 days (Days 2-6), Ara-C (Cytarabine) $2 \mathrm{mg} / \mathrm{m}^{2}$ given via an infusion (drip) over 4 hours, once a day (4 hours after the Fludarabine) for 5 days (Days 2-6), Idarubicin $10 \mathrm{mg} / \mathrm{m}^{2}$ given via Bolus injection once a day for 3 days (Days 4-6)] in 3 cases. The pre-transplant chemotherapy was given up to the maximum response as assessed clinically.

\section{Pre-transplant work-up and transplant protocol}

Initial evaluation included history, physical examination. Details of prior treatment were recorded. Investigations including complete blood count including differential count; renal and liver function tests; BM examination, MUGA Scan, pulmonary function test, 24 hours urine creatinine clearance and dental check-up were performed for all patients. All patients were informed of the details of the procedure and any potential complications. Written informed consent was obtained. A central line (Perm-a-cath) was inserted.

\section{Stem cell mobilization and collection}

The source of Stem Cell in all the transplant cases was peripheral blood. For mobilization of PBSCs, patients received growth factors as an injection of G-CSF $10 \mathrm{mcg} / \mathrm{kg}$ once daily subcutaneous for 5 days in the nadir of the blood counts (the lowest blood count after chemotherapy) from salvage chemotherapy, or stem cell was collected after cyclophosphamide $1.5 \mathrm{mg} / \mathrm{m}^{2}$ single dose intravenous followed by G-CSF $10 \mu \mathrm{g} / \mathrm{kg}$ OD $\mathrm{SC}$, or stem cell was collected following administration of G-CSF alone $10 \mu \mathrm{g} / \mathrm{kg}$ once daily subcutaneous.

Table 5. Shows stem cell mobilization in all patients

\begin{tabular}{lllll}
\hline & NHL 45 patients & HL 36 patients & MM 33 patients & $\begin{array}{l}\text { AML 5 patients } \\
\mathbf{( 4 . 2 \% )}\end{array}$ \\
\hline Post chemotherapy \& G-CSF & $\mathbf{( 3 7 . 8 \% )}$ & $\mathbf{( 3 0 . 2 \% )}$ & $\mathbf{( 2 7 . 7 \% )}$ & \\
Cytoxan \& G-CSF & 21 cases $(13.3 \%)$ & 3 cases $(10 \%)$ & & \\
G-CSF alone & 18 cases $(40 \%)$ & 22 cases $(73.3 \%)$ & 27 cases $(81.8 \%)$ & 1 case \\
\hline
\end{tabular}


Leukapheresis was started on day 5 of G-CSF either when given alone or post-chemotherapy, when CD34+ count in peripheral blood was $\geq 20 / \mu \mathrm{L}$, from subclavian vein using perm-a-catheter, on COBE-SPECTRA machine the automated or the manual one. Medians of two leukaphereses sessions were performed (Range 1-3). Target CD 34+ count was $5 \times$ $10^{6} / \mathrm{kg}$. A sample of stem cells was obtained and total cell counts were determined using an automated cell counter; the differential cell count was done manually. For CD34 counts, cells were labeled with fluorescein-conjugated anti-CD34 and analyzed using Coulter FC500 flow cytometer to yield an absolute CD34 count. Stem cells were cryopreserved at $-80^{\circ} \mathrm{C}$ using a $10 \%$ DMSO (Dimethyl sulfoxide) in autologous plasma. The procedure was well tolerated, with only $20 \%$ of patients having circumoral and peripheral numbness, which solved with calcium gluconate administration.

\section{Conditioning Regimens and supportive care}

In Non-Hodgkin ‘s and Hodgkin' Lymphomas BEAM carmustine (BiCNU), etoposide, cytarabine arabinoside, melphalan] was used in 59 patients (72.8\%), BEAC (Melphalan was not available so cyclophosphamide was used) in 15 patients (18.5\%), CEAM ( BiCNU was not available so it was replaced by CCNU) in 6 patients (7.4\%), and Zevalin-BEAM was used in one NHL-DLBCL patient. All Multiple Myeloma patients received melphalan $200 \mathrm{mg} / \mathrm{m}^{2}$ except one patient received melphalan $140 \mathrm{mg} / \mathrm{m}^{2}$ because of renal impairment ( 24 hour creatinine clearance was $<30 \mathrm{~mL} / \mathrm{min}$ ). Acute Myeloid Leukemia patients received cyclophosphamide and Etoposide. The conditioning regimen was tolerated well, 56 patients (46.7\%) didn't have significant symptoms, 30 patients (25\%) had grade I nausea \&vomiting, had 44 patients $(28.3 \%)$ had grade II nausea, vomiting, and mucositis.

\section{Stem cell infusion}

Stem cells were removed from the deep freezer and thawed at room temperature on a water bath. Stem cells were infused $24 \mathrm{~h}$ after conditioning regimen. Stem cell viability after thawing ranged from $72 \%$ to $85 \%$, cell loss due to cryopreservation ranged from $15 \%-28 \%$. Autologous blood stem cells were re-infused on day 0 through a central venous catheter. The cells infused were: TNC $10.47 \pm 7.31 \times 10^{8} / \mathrm{kg}, \mathrm{MNC} 4.87 \pm 6.30 \times 10^{8} / \mathrm{kg}, \mathrm{CD} 34+3.92 \pm 3.64 \times 10^{6} / \mathrm{kg}$, CFU $1328.77 \pm 1094 \times 10^{4} / \mathrm{kg}$. Patients received prophylactic acyclovir $5 \mathrm{mg} / \mathrm{kg}$ every 8 hours and fluconazole $200 \mathrm{mg}$ i.v. once daily starting from Day +1 post stem cell infusion. Ciprofloxacin prophylaxis was started when absolute neutrophil count was $\leq 500 / \mu \mathrm{L}$. Day 5 onwards patients received growth factor G-CSF $5 \mathrm{mcg} / \mathrm{kg}$ daily subcutaneous until engraftment. All the blood products transfused during the post- transplant period were irradiated with 25 Gy. Posttransplantation, weekly surveillance for CMV in blood by PCR and twice weekly blood, stool, throat and urine culture were carried out in all patients. Neutropenia was defined as an $\mathrm{ANC}<0.5 \times 10^{3} / \mu \mathrm{L}$. For fever $\geq 37.8^{\circ} \mathrm{C}$ all patients were subjected to microbial blood cultures, cultures from other sites were collected as clinically indicated, and blood sample for procalcitonin level assessment was withdrawn. For neutropenic fever $\geq 37.8^{\circ} \mathrm{C}$ all patients initially received broad-spectrum intravenous antibiotics (Piperacillin/Tazobactam and Amikacin), as per the antibiotic guidelines of the center. Later these antibiotics were individually modified according to microbial culture and sensitivity data as well as patient's response. Patient data were obtained from the Stem Cell Transplant Unit, which contains prospectively collected data on all patients undergoing transplant therapy at our center. The post-transplant time period was reviewed for positive culture results starting from the stem cell infusion until day +30 following stem cell transplantation. Blood, stool, throat and urine culture results as well as all pathological data were obtained from the hospital laboratory records and/or medical charts. Culture isolates were recorded as separate infection episodes if isolated $>1$ week apart for blood or $>4$ weeks apart for stool. Culture-negative febrile episodes were included in this analysis. The number of infectious episodes was calculated in the whole cohort.

\section{Statistical analysis}

Using these data, we performed all statistical analyses using an IBM - compatible computer and the Statistical Package of Social Sciences (SPSS) 17 program for Windows 7 (SPSS, Inc., Chicago, IL.). We calculated the descriptive statistics, including the mean, median, range, number, percentage (Frequency distributions), ratio, for each group of interest and regression analysis of the relevant risk factors. 
Table 6. Patients with specific infections

\begin{tabular}{|c|c|c|c|c|c|c|c|c|c|}
\hline $\begin{array}{l}\text { Type of } \\
\text { infection }\end{array}$ & $\begin{array}{l}\text { Total } \\
\text { patients }\end{array}$ & $\begin{array}{l}\text { Gram + } \\
\text { isolates }\end{array}$ & $\begin{array}{l}\text { Total } \\
\text { patients }\end{array}$ & $\begin{array}{l}\text { Gram - } \\
\text { isolates }\end{array}$ & $\begin{array}{l}\text { Total } \\
\text { patients }\end{array}$ & $\begin{array}{l}\text { Mixed Gram + } \\
\text { isolates \& Gram } \\
\text {-isolates }\end{array}$ & $\begin{array}{l}\text { Total } \\
\text { patient } \\
\mathrm{s}\end{array}$ & Fungi & $\begin{array}{l}\text { Total } \\
\text { patients }\end{array}$ \\
\hline \multirow{5}{*}{$\begin{array}{l}\text { Blood } \\
\text { stream } \\
\text { infection } \\
\text { (Central- } \\
\text { venous } \\
\text { catheter } \\
\text { associated) }\end{array}$} & 17 & 6 & & 9 & & 1 & & 1 & \\
\hline & & $\begin{array}{l}\text { Coagulase } \\
\text { negative } \\
\text { staphylococ } \\
\text { ci }\end{array}$ & 3 & E.coli & 4 & $\begin{array}{l}\text { Morganellamorganii, } \\
\text { E.coli, klebsiella, } \\
\text { Staphylococcus aureus }\end{array}$ & 1 & $\begin{array}{l}\text { Candida } \\
\text { albicans }\end{array}$ & 1 \\
\hline & & $\begin{array}{l}\text { Staphyloco } \\
\text { ccus aureus }\end{array}$ & 1 & klebsiella & 2 & & & & \\
\hline & & $\begin{array}{l}\text { Viridans } \\
\text { streptococci }\end{array}$ & 1 & acinetobacter & 2 & & & & \\
\hline & & $\begin{array}{l}\text { Staphyloco } \\
\text { ccus } \\
\text { epidermidis }\end{array}$ & 1 & $\begin{array}{l}\text { Chromobacte } \\
\text { riumviolaceu } \\
\mathrm{m}\end{array}$ & 1 & & & & \\
\hline \multirow{5}{*}{$\begin{array}{l}\text { Respiratory } \\
\text { tract } \\
\text { infections }\end{array}$} & 4 & & & 4 & & & & & \\
\hline & & & & Klebsiella & 1 & & & & \\
\hline & & & & Acinetobacter & 1 & & & & \\
\hline & & & & $\begin{array}{l}\text { Pseudomonas } \\
\text { aeruginosa }\end{array}$ & 1 & & & & \\
\hline & & & & $\begin{array}{l}\text { Haemophillus } \\
\text { influenza }\end{array}$ & 1 & & & & \\
\hline \multirow{2}{*}{$\begin{array}{l}\text { Gastrointest } \\
\text { inal }\end{array}$} & 1 & & & 1 & & & & & \\
\hline & & & & Salmonella & 1 & & & & \\
\hline \multirow{3}{*}{$\begin{array}{l}\text { Urinary } \\
\text { tract } \\
\text { infection }\end{array}$} & 2 & & & 2 & & & & & \\
\hline & & & & $\begin{array}{l}\text { Multiresistent } \\
\text { Pseudomonas } \\
\text { aeruginosa }\end{array}$ & 1 & & & & \\
\hline & & & & $\begin{array}{l}\text { Enterobacter } \\
\text { cloacae- } \\
\text { ESBL }\end{array}$ & 1 & & & & \\
\hline \multirow{2}{*}{$\begin{array}{l}\text { Skin \& soft } \\
\text { tissue }\end{array}$} & 1 & & & 1 & & & & & \\
\hline & & & & $\begin{array}{l}\text { Pseudomonas } \\
\text { aeruginosa }\end{array}$ & 1 & & & & \\
\hline
\end{tabular}

Note: Stool analysis showed stongloidiasis in three patients

\section{Results}

The mean time for engraftment was 12 days (Range 9-14) in Non-Hodgkin s Lymphomas, 11 days (Range 9-15 days) in Hodgkin' Lymphomas, 12 days (Range 9-14 days) in Multiple Myeloma, 12 days (Range 11-13 days) in Acute Myeloid Leukemia. The mean time for engraftment for all patients was 11 days. The mean duration of severe neutropenia was 7 days (Range 5-9) in all the patients. After transplant the patients received a mean of 2 units packed red blood cells and 4 units of platelets concentrates (Each 1 represents 6 units of pooled random donor platelets). The mean time for platelet transfusion independence was 11 days. The mean duration of growth factor use (Started on day 5 post-transplant) was 9 
days. All routine cultures and swabs showed commensal flora. A total of 92 patients (76.7\%) had febrile episodes at a median of 7 days (Range -2 to 23 days), whereas 28 patients (23.3\%) didn't have any fever spikes. Infections could be documented clinically only in 67 patients $(72.8 \%)$ where they had culture-negative infections. Infections could be documented clinically and microbiologically, with isolation of in a total of 25 patients (27.2\%). The most common sites of infections were blood stream infections in 17 patients (68\%), gastrointestinal in one patient (4\%), pulmonary infection in 4 patients (16\%), skin and subcutaneous tissue in one patient (4\%), urinary tract infection (UTI) in two patient $(8 \%)$. Gram-negative isolates were found in 17 patients (68\% of culture-positive febrile episodes). The isolates included Escherichia coli, enterobacter, acinetobacter, klebsiella and Pseudomonas aeruginosa. Gram positive isolates were found in 6 patients (24\% of culture-positive febrile episodes). Gram- positive isolates included Staphylococcus aureus, Staphylococcus epidermidis, Staphylococcus hemolyticus, and Streptococcus viridians. Mixed Gram negative and Gram positive isolates were found in one patient (4\%). Fungi were isolated in one patient (4\%). Seventeen patients (68\%) had Blood stream infections, isolates were Gram-positive in six patients (35.3\%), Gram-negative in nine patients (41.2\%), mixed Gram-negative and Gram-positive in one patient and fungi in one patient. One patient had enterocolitis due to Salmonella infection and three patients had enterocolitis due to Strongloidiasis. Two patients had Gram-negative urinary tract infections. Table 6 shows the microbiological isolates.

Despite the use of ciprofloxacin for anti-bacterial prophylaxis, seventeen patients $(68 \%)$ developed infections with Gram-negative organisms; seven of these isolates (41.2\%) were sensitive to ciprofloxacin. There was no statistically significant correlation between the number of CD34+ cells infused and hematopoietic recovery in Lymphoma, Myeloma, and AML patients among both sex and in different patients' ages, all patients had prompt comparable myeloid engraftment. Multivariate analyses did not reveal any significant correlation between infection incidence and studied variables cell dose infused (CD34+ count and mononuclear cell count), time to engraftment, the duration of severe neutropenia, the underlying hematological diagnosis and the response to salvage chemotherapy complete remission versus partial remission (Table 7). During the 30-day follow-up period only one patient died secondary to sepsis and respiratory failure.

Table 7. Regression analysis showing febrile episodes didn't correlate with the number of CD34+ cells infused, the time until engraftment, the duration of severe neutropenia, and the underlying hematological diagnosis

\begin{tabular}{|c|c|c|c|c|c|c|c|}
\hline \multicolumn{8}{|l|}{ Coefficients $^{\mathrm{a}}$} \\
\hline \multirow[t]{2}{*}{ Model } & \multicolumn{2}{|c|}{ Unstandardized coefficients } & Standardized coefficients & $\mathrm{t}$ & Sig. & \multicolumn{2}{|c|}{$95 \%$ Confidence interval for $\mathrm{B}$} \\
\hline & $\mathrm{B}$ & Std. error & Beta & & & Lower bound & Upper bound \\
\hline $\mathrm{CD} 34+\times 10^{6} / \mathrm{kg}$ & .008 & .012 & .069 & .664 & .508 & -.016 & .033 \\
\hline $\mathrm{MNC} \times 10^{8} / \mathrm{kg}$ & -.005 & .007 & -.070 & -.670 & .504 & -.019 & .009 \\
\hline $\begin{array}{l}\text { Time to } \\
\text { entgraftment }\end{array}$ & -.019 & .021 & -.129 & -.949 & .345 & -.060 & .021 \\
\hline Duration of severe & & & & & & & \\
\hline Neutropenia & .012 & .020 & .083 & .604 & .547 & -.028 & .053 \\
\hline NHL, HL, MM ${ }^{b}$ & .013 & .035 & .037 & .378 & .707 & -.056 & .082 \\
\hline
\end{tabular}

Note: Dependent Variable: INFECTION

Abbreviations: NHL = Non-Hodgkin's lymphoma; HL = Hodgkin's lymphoma;MM = Multiple myeloma

\section{Discussion}

In this report we describe the incidence of culture negative and culture-proven microbiological infections during the first 30 days following autologous PBSC transplantation. The autologous transplant recipient is vulnerable to infection during the pre and immediate post engraftment periods. We anticipated a risk of infectious complications. However, twenty eight patients $(23.3 \%)$ didn't have any fever spikes. A total of 92 patients $(76.7 \%)$ had short-lived febrile episodes without substantial morbidity and mortality. The observed high incidence of clinically diagnosed infections without cultures and 
relatively low incidence of proven infection might be attributable to the prophylactic antimicrobials administered in the post-transplant period. In addition, the use of G-CSF hastening hematopoietic recovery post-transplant may have contributed to the observed incidence of infections were $23.3 \%$ of the patients did not have any infections, the shortened post transplant infections with its complications. The G-CSF administered following transplant can reduce the time to engraftment and the risk of post-transplant infections ${ }^{[17]}$. Also, in a variety of transplant-and non-transplant-related settings G-CSF can enhance neutrophil function ${ }^{[18,19]}$. Previous reports describe up to $12 \%$ of transplant patients developing invasive infections with Candida species after SCT, with substantial morbidity and mortality ${ }^{[20]}$. One of the major risk factors for the development of candidiasis is the duration of neutropenia. Fluconazole has demonstrated efficacy in reducing the incidence of both colonization and infection with Candida species in SCT and leukemia patients ${ }^{[21,22]}$. C. krusei and C. glabrataare most often resistant to the azole antifungals ${ }^{[21]}$. Patients with GI colonization with these organisms may suffer added risks for developing bacteremia with enteric bacteria, possibly as a result of tissue damage augmented by the mucosal yeast adherence ${ }^{[22]}$. We observed a relatively high incidence of blood stream infections (Central venous catheter-associated bacteremia) secondary to Gram-negative isolates as well as a modest number of coagulase-negative Staphylococcus isolates. However, Salazar et al. ${ }^{[23]}$ found that Gram-positive bacteria were responsible for $75 \%$ of bacteremias, one-third of which were caused by Staphylococcus epidermidis in a retrospective review of 126 patients undergoing auto-transplantation receiving prophylaxis with ciprofloxacin, itraconazole and acyclovir. A similar incidence of neutropenia- associated complications with a 39\% incidence of bacteremia among 66 patients. Gram-positive cocci were the predominant pathogens were found by Kolbe et al. ${ }^{[24]}$. In a study by Offidani et al. ${ }^{[25]}$ the incidence of infective complications in 150 patients undergoing stem cell transplant was found $13 \%$ Gram-positive and 10\% incidence of Gram-negative bacteremia, despite prophylaxis with quinolones and fluconazole. A somewhat similar incidence of bacteremia (13\%) in 127 breast cancer patients undergoing transplantation, with minimal antibiotic prophylaxis using trimethoprim-sulfamethoxazole in only $6 \%$ of patients was reported by Barton et al. ${ }^{[26]}$. In our review Gram-negative isolates were the predominant pathogens, $42.2 \%$ of them were sensitive to ciprofluxacin. In the preengraftment period, the major risk for acquiring infection is neutropenia and altered barrier defenses resulting from the BMT conditioning regimen ${ }^{[2-5]}$. Another factor is the need for vascular access in this group of patients ${ }^{[2,3,21]}$. The sources of pathogens for infection during this period are the patient's skin flora, oral flora, and GI tract flora ${ }^{[3]}$. The disruption of the normal barrier defenses allows microorganisms that normally colonize these areas to invade, rendering them pathogenic. The GI flora that usually colonizes the GI tract (i.e., gram-negative organisms, anaerobes, and Candida species) becomes pathogenic in the immunocompromised state ${ }^{[5]}$. The major concern with the use of prophylactic antibiotics is the development of resistant organisms. Reports of fluoroquinolone resistance in coagulase-negative staphylococci and in E coli have emerged ${ }^{[55,57]}$. This might explain the observed relatively higher incidence of Gram-negative isolates in our review. We had modest duration of neutropenia. Besides none of our CMV sero-positive patients had CMV antigenemia and disease during the study period. This is consistent with earlier reports which showed low incidence of CMV antigenemia and disease ${ }^{[27-29]}$.

In conclusion, this retrospective review showed the incidence and consequences of infections following high dose chemotherapy and autologous stem cell transplant in Kuwait Cancer control - Stem Cell transplantation Unit. The duration of severe neutropenia was modest. Infections following stem cell transplant were not life threatening but required specific measures to be reversed. Careful prophylaxis, surveillance and attentive supportive care can limit the infectious hazards.

\section{References}

[1] Stat of Kuwait: The Public Authority for Civil information. Available from http://www.paci.gov.kw/.Accessed 29 March 2010.

[2] Kyle R, Rajkumar SV. Multiple myeloma. Blood 2008;111:2962-72. PMid:18332230 http://dx.doi.org/10.1182/blood-2007-10-078022

[3] Kumar L, Vikram P, Kochupillai V. Multiple myeloma: Recent advances in management. Nat Med J India 2006;19:80-89. PMid:16756196 
[4] Selby PJ, Mac Elwain TJ, Nandi AC, Ferren TJ, Powles RL, Tillyer CR et al. Multiple myeloma treated with high dose intravenous melphalan. Br J Haematol 1987;66:55-62. PMid:3593657 http://dx.doi.org/10.1111/j.1365-2141.1987.tb06890.x

[5] Powles R, Raje N, Milan S, Millar B, Shepherd V, Mehta J et al. Outcome assessment of a population based group of 195 unselected myeloma patients under 70 years of age offered intensive treatment. Bone Marrow Transplant 1997;20:435-43. PMid:9313875 http://dx.doi.org/10.1038/sj.bmt.1700917

[6] Blade J, Esteve J, Rives S, Martı' nez C, Rovira M, Urbano-Ispizua A et al. High-dose therapy autotransplantation intensification vs. continued standard chemotherapy in multiple myeloma in first remission. Results of a non-randomized study from a single institution. Bone Marrow Transplant 2000;26:845-49. PMid:11081383 http://dx.doi.org/10.1038/sj.bmt.1702622

[7] Desikan R, Barlogie B, Sawyer J, Ayers D, Tricot G, Badros A et al. Results of high-dose therapy for 1000 patients with multiple myeloma: Durable complete remissions and superior survival in the absence of chromosome 13 abnormalities. Blood 2000;95:4008-10. PMid:10845942

[8] Attal M, Harousseau JL, Stoppa AM, Sotto JJ, Fuzibet JG, Rossi JF et al. A prospective randomized trial of autologous bone marrow and chemotherapy in multiple myeloma. N EnglJ Med 1996;335:91-97. PMid:8649495 http://dx.doi.org/10.1056/NEJM199607113350204

[9] Child JA, Morgan GJ, Davies FE, Owen RG, Bell SE, Hawkins K et al. Medical Research Council Adult Leukemia Working Party high-dose chemotherapy with hematopoietic stem-cell rescue for multiple myeloma. New Engl J Med 2003;348:1875-83. PMid:12736280 http://dx.doi.org/10.1056/NEJMoa022340

[10] Fermand JP, Katsahian S, Divine M, Leblond V, Dreyfus F, Macro M et al High-dose therapy and autologous stem cell compared with conventional treatment in myeloma patients aged 55 to 65 years: Long term results of a randomized control trial from the Group Myelome-Autogreffe. J Clin Oncol 2005;23:9227-33. PMid:16275936 http://dx.doi.org/10.1200/JCO.2005.03.0551

[11] Lenhoff S, Hjorth M, Holmberg I, Turesson I, Westin J, Nielssen JL et al. Impact on survival of high dose therapy with autologous stem cell support in patients younger than 60 years with newly diagnosed multiple myeloma: A population based study. Blood 2000;95:7-11. PMid:10607678

[12] Koreth J, Cutler CS, Djulbegovic B, Behl R, Schlossman RL, Munshi NC et al. High-dose therapy with single autologous transplantation versus chemotherapy for newly diagnosed multiple myeloma: A systematic review and meta-analysis of randomized controlled trials. Biol Blood Marrow Transplant 2007;13:183-96. PMid:17241924 http://dx.doi.org/10.1016/j.bbmt.2006.09.010

[13] Levy V, Katsahian S, Fermand JP, Mary JY, Chevret S. A meta-analysis on data from 575 patients with multiple myeloma randomly assigned to either high dose therapy or conventional therapy. Medicine 2005;84:250-60. http://dx.doi.org/10.1097/01.md.0000173272.71949.a1

[14] Jagannath S, Vesole DH, Zhang M et al. Feasibility and cost effectiveness of outpatient auto transplants in multiple myeloma.

[15] Bone Marrow Transplant 1997;20:445-50. PMid:9313876 http://dx.doi.org/10.1038/sj.bmt.1700900

[16] Gluck S, des Rochers C, Cano C et al. High-dose chemotherapy followed by autologous blood cell transplantation: A safe and effective outpatient approach. Bone Marrow Transplant1997; 20:431-34. PMid:9313874 http://dx.doi.org/10.1038/sj.bmt.1700901

[17] Freeman, H. P. (2004). Poverty, culture, and social injustice: Determinants of cancer disparities. CA: A Cancer Journal for Clinicians,54:72-77. http://dx.doi.org/10.3322/canjclin.54.2.72

[18] Kagawa-Singer, M., Dadia, A. V., Yu, M. C., \& Surbone, A. (2010). Cancer, culture, and health disparities: Time to chart a new course? CA: A Cancer Journal for Clinicians, 60,12-39. PMid:20097836 http://dx.doi.org/10.3322/caac.20051

[19] Jones, S. (2000). Medical aspects of expatriate health: Health threats. Occupational Medicine (Oxford, England), 50,572-78. PMid:11220025 http://dx.doi.org/10.1093/occmed/50.8.572

[20] Lei, L., Liang, Y. X., \& Krieger, G. R. (2004). Stress in expatriates. Clinics in Occupa-tional and Environmental Medicine, 4,221-29. Herrmann RP, Trent M, Cooney J, Cannell PK. Infections in patients managed at home during autologous stem cell transplantation for lymphoma and multiple myeloma. Bone Marrow Transplant 1999;24:1213-17.

[21] Stahel RA, Jost LM, Cerny T et al. Randomized study of recombinant human granulocyte colony-stimulating factor after high-dose chemotherapy and autologous bone marrow transplantation for high-risk lymphoid malignancies. J ClinOncol1994;12:1931-38. PMid:7521907

[22] Calderwood S, Kilpatrick L, Douglas SD et al. Recombinant human granulocyte colony-stimulating factor therapy for patients with neutropenia and/or neutrophil dysfunction secondary to glycogen storage disease type 1b. Blood 2001;97:376-82. PMid:11154211 http://dx.doi.org/10.1182/blood.V97.2.376

[23] Wang X, Clowes C, Duarte R, Pu QQ. Expression of CD11b/CD18 on neutrophils after consolidation chemotherapy for acute myeloid leukemia and after high dose chemotherapy with autologous haematopoietic stem cell transplantation. Int J Oncol 2000;17:597-602. PMid:10938404 
[24] Verfaillie C, Weisdorf D, Haake R et al. Candida infections in bone marrow transplant recipients. Bone Marrow Transplant1991;8:177-84. PMid:1958898

[25] Goodman JL, Winston DJ, Greenfield RA et al. A controlled trial of fluconazole to prevent fungal infections in patients undergoing bone marrow transplantation. New Engl J Med 1992;326:845-51. PMid:1542320 http://dx.doi.org/10.1056/NEJM199203263261301

[26] Winston DJ, Chandrasekar PH, Lazarus HM et al. Fluconazole prophylaxis of fungal infections in patients with acute leukemia. Results of a randomized placebo-controlled, double-blind, multicenter trial. Ann Intern Med 1993;118:495-503. PMid:8442620

[27] Salazar R, Sola C, Maroto P et al. Infectious complications in 126 patients treated with high-dose chemotherapy and autologous peripheral blood stem cell transplantation. Bone Marrow Transplant 1999;23:27-33. PMid:10037047 http://dx.doi.org/10.1038/sj.bmt.1701520

[28] Kolbe K, Domkin D, Derigs HG et al. Infectious complications during neutropenia subsequent to peripheral blood stem cell transplantation. Bone Marrow Transplant 1997;19:143-47. PMid:9116611 http://dx.doi.org/10.1038/sj.bmt.1700621

[29] Offidani M, Corvatta L, OlivieriA et al. Infectious complications after autologous peripheral blood progenitor cell transplantation followed by G-CSF. Bone Marrow Transplant 1999;24:1079-87. PMid:10578158 http://dx.doi.org/10.1038/sj.bmt.1702033

[30] Barton T, Collis T, Stadtmauer E, Schuster M. Infectious complications the year after autologous bone marrow transplantation or peripheral stem cell transplantation for treatment of breast cancer. Clin Infect Dis 2001;32:391-95. PMid:11170946 http://dx.doi.org/10.1086/318491

[31] van Burik J, Weisdorf D. Infections in recipients of blood and marrow transplantation. In: Mandell GL, Bennett JE, Dolin R, eds. Principles and Practice of Infectious Diseases. 5th ed. Philadelphia, Pa: Churchill Livingstone; 2000:3136-47.

[32] CDC. Guidelines for preventing opportunistic infections among hematopoietic stem cell transplant recipients. MMWR Recomm Rep. Oct 2000;49 (RR-10):1-125, CE1-7. [Medline].

[33] Leather HL, Wingard JR. Infections following hematopoietic stem cell transplantation. Infect Dis Clin North Am. Jun 2001;15(2):483-520. [Medline]. http://dx.doi.org/10.1016/S0891-5520(05)70157-4

[34] Sable CA, Donowitz GR. Infections in bone marrow transplant recipients. Clin Infect Dis. Mar 1994;18(3):273-81; quiz 282-84. [Medline]. PMid:8011804 http://dx.doi.org/10.1093/clinids/18.3.273

[35] van Burik JA, Weisdorf DJ. Infections in recipients of blood and marrow transplantation. Hematol Oncol Clin North Am. Oct 1999;13(5):1065-89, viii. [Medline]. http://dx.doi.org/10.1016/S0889-8588(05)70110-6

[36] Murphy M, Brown AE, Sepkowitz KA, et al. Fluoroquinolone prophylaxis for the prevention of bacterial infections in patients with cancer--is it justified? Clin Infect Dis. Aug 1997;25(2):346-48. [Medline]. PMid:9332551 http://dx.doi.org/10.1086/516925

[37] Cometta A, Calandra T, Bille J, Glauser MP. Escherichia coli resistant to fluoroquinolones in patients with cancer and neutropenia. N Engl J Med. Apr 28 1994;330(17):1240-41. [Medline]. PMid:8139646 http://dx.doi.org/10.1056/NEJM199404283301717

[38] Singhal S, Powles R, Treleaven J et al. Cytomegaloviremiaafter autografting for leukemia: Clinical significance and lack of effect on engraftment. Leukemia 1997;11:835-38. PMid:9177437 http://dx.doi.org/10.1038/sj.leu.2400672

[39] Bilgrami S, Aslanzadeh J, Feingold JM et al. Cytomegalovirus viremia, viruria and disease after autologous peripheral blood stem cell transplantation: No need for surveillance. Bone Marrow Transplant 1999;24:69-73. PMid:10435738 http://dx.doi.org/10.1038/sj.bmt.1701827

[40] Chakrabarti S, Collingham KE, Stevens RH et al. Isolation of viruses from stools in stem cell transplant recipients: A prospective surveillance study. Bone Marrow Transplant 2000;25:277-82. PMid:10673699 http://dx.doi.org/10.1038/sj.bmt.1702164 